\title{
Effect of D- $\alpha$-tocopherol on tubular nephron acidification by rats with induced diabetes mellitus
}

G. Nascimento Gomes ${ }^{1}$, F.T. Barbosa ${ }^{1}$, R.F. Radaeli ${ }^{1}$, M.F. Cavanal ${ }^{1}$, M. Mello Aires ${ }^{2}$ and F. Zaladek Gil ${ }^{1}$

\author{
${ }^{1}$ Departamento de Fisiologia, Escola Paulista de Medicina, \\ Universidade Federal de São Paulo, São Paulo, SP, Brasil \\ ${ }^{2}$ Departamento de Fisiologia e Biofísica, Instituto de Ciências Biomédicas, \\ Universidade de São Paulo, São Paulo, SP, Brasil
}

Correspondence

G. Nascimento Gomes

Departamento de Fisiologia, UNIFESP

Rua Botucatu, 862, 5으 andar

04023-900 São Paulo, SP

Brasil

Fax: +55-11-5575-9165

E mail: guiomar@ecb.epm.br

Research supported by FAPESP

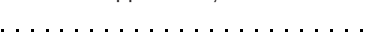

Received July 30, 2004

Accepted March 9, 2005

\begin{abstract}
The objective of the present study was to determine if treatment of diabetic rats with $\mathrm{D}$ - $\alpha$-tocopherol could prevent the changes in glomerular and tubular function commonly observed in this disease. Sixty male Wistar rats divided into four groups were studied: control (C), control treated with D- $\alpha$-tocopherol $(\mathrm{C}+\mathrm{T})$, diabetic (D), and diabetic treated with $\mathrm{D}$ - $\alpha$-tocopherol $(\mathrm{D}+\mathrm{T})$. Treatment with $\mathrm{D}$ - $\alpha$-tocopherol $(40 \mathrm{mg} / \mathrm{kg}$ every other day, ip) was started three days after diabetes induction with streptozotocin $(60 \mathrm{mg} / \mathrm{kg}$, $i p$ ). Renal function studies and microperfusion measurements were performed 30 days after diabetes induction and the kidneys were removed for morphometric analyses. Data are reported as means \pm SEM. Glomerular filtration rate increased in $\mathrm{D}$ rats but decreased in $\mathrm{D}+\mathrm{T}$ rats $\left(\mathrm{C}: 6.43 \pm 0.21 ; \mathrm{D}: 7.74 \pm 0.45 ; \mathrm{D}+\mathrm{T}: 3.86 \pm 0.18 \mathrm{ml} \mathrm{min}^{-1}\right.$ $\left.\mathrm{kg}^{-1}\right)$. Alterations of tubular acidification observed in bicarbonate absorption flux $\left(\mathrm{JHCO}_{3}\right)$ and in acidification half-time (t/2) in group $\mathrm{D}$ were reversed in group D + T $\left(\mathrm{JHCO}_{3}, \mathrm{C}: 2.30 \pm 0.10\right.$; D: $3.28 \pm$ $0.22 ; \mathrm{D}+\mathrm{T}: 1.87 \pm 0.08 \mathrm{nmol} \mathrm{cm} \mathrm{cm}^{-2}$; t/2, C: $4.75 \pm 0.20 ; \mathrm{D}: 3.52 \pm$ 0.15 ; D + T: $5.92 \pm 0.19 \mathrm{~s}$ ). Glomerular area was significantly increased in $\mathrm{D}$, while $\mathrm{D}+\mathrm{T}$ rats exhibited values similar to $\mathrm{C}$, suggesting that the vitamin prevented the hypertrophic effect of hyperglycemia (C: $8334.21 \pm 112.05$; D: 10,217.55 \pm 100.66 ; D + T: $8478.21 \pm$ $\left.119.81 \mu \mathrm{m}^{2}\right)$. These results suggest that $\mathrm{D}$ - $\alpha$-tocopherol is able to protect rats, at least in part, from the harmful effects of diabetes on renal function.
\end{abstract}

\section{Introduction}

Although diabetic nephropathy is the most common single cause of end-stage renal disease in the United States and in Europe $(1,2)$, the mechanism that underlies this ef-
Key words

- Diabetes

- D- $\alpha$-tocopherol

- Renal function

- Nephropathy fect is not entirely clear. Hyperglycemia has been shown to be the major cause of the pathological changes that occur in diabetes. Some biochemical pathways that have been shown to be involved in the pathogenesis of diabetes are: the activation of protein kinase 
C isoforms (3), the increased glucose flux through the aldose reductase pathway increasing the production of sorbitol (4), and increased formation of glucose-derived advanced glycation end products (AGEs) $(5,6)$.

AGEs are the result of the non-enzymatic glycation/oxidation of amino acids in proteins but can also be formed from lipids and lipoproteins (7). Tissue accumulation of AGEs is associated with toxic effects that include cross-linking of long-lived proteins such as collagens and other matrix proteins, vascular permeability changes, and promotion of mononuclear cell influx. Furthermore, AGEs have been shown to induce genes for growth factors, extracellular matrix proteins and inflammatory cytokines, as well as to stimulate cell proliferation (7). AGEs have also been shown to quench nitric oxide, and have been implicated in the pathogenesis of atherosclerosis $(5,6)$.

Excess glucose metabolism through the polyol pathway can stimulate de novo synthesis of both diacylglycerol (DAG) and phosphatidic acid, which may account for the increased protein kinase $\mathrm{C}$ (PKC) activation/translocation observed in mesangial cells (8). Increased intracellular glucose causes generation of reactive oxygen species that may directly activate PKC isozymes and enhance their reactivity to vasoactive peptide signaling. In both rodent models of diabetes and cultured mesangial cells, PKC appears to be the key isozyme required for the enhanced expression of transforming growth factor-1, initiation of early accumulation of mesangial matrix protein, and increased microalbuminuria (8).

The mammalian renal proximal tubule is the major nephron segment responsible for $\mathrm{NaCl}$ and $\mathrm{NaHCO}_{3}$ absorption from the glomerular filtrate, a transport mediated by the apical membrane $\mathrm{Na}^{+} / \mathrm{H}^{+}$exchanger $(\mathrm{NH} 3$ isoform) $(9,10)$.

In previous study from our laboratory, we have shown that in rats with diabetes induced by intraperitoneal (ip) injection of streptozotocin, there is an increase in the rate of $\mathrm{HCO}_{3}{ }^{-}$absorption, possibly effected by a higher density of $\mathrm{Na}^{+} / \mathrm{H}^{+}$antiporter in the luminal membrane of proximal tubules (11). Increased erythrocyte $\mathrm{Na}^{+} / \mathrm{Li}^{+}$countertransport (12) and increased leukocyte and fibroblast $\mathrm{Na}^{+} / \mathrm{H}^{+}$antiport activity have also been demonstrated in type I diabetic patients with hypertension and nephropathy $(13,14)$.

$D$ - $\alpha$-tocopherol, the most active form of vitamin $\mathrm{E}$, is an antioxidant that affects various membrane-bound enzyme systems and has been shown to prevent activation of PKC (15). However, few in vivo studies are available about the influence of D- $\alpha$-tocopherol on diabetic nephropathy. Thus, the objectives of the present study were to determine if the treatment of diabetic rats with D$\alpha$-tocopherol could prevent the changes in glomerular function and tubular nephron acidification usually seen in this experimental model.

\section{Material and Methods}

Male Wistar rats, 3 months old, were obtained from Escola Paulista de Medicina, EPM. Sixty rats were divided into four groups: control (C), control treated with D- $\alpha$-tocopherol $(\mathrm{C}+\mathrm{T})$, diabetic (D), and diabetic treated with $\mathrm{D}-\alpha$-tocopherol $(\mathrm{D}+\mathrm{T})$. Diabetic state was induced by injecting streptozotocin $(60 \mathrm{mg} / \mathrm{kg}$, ip $)$. Three days after injection, the diabetic status was confirmed by measuring the level of glycemia (animals that presented values below $200 \mathrm{mg} \%$ were discarded) and treatment with $\mathrm{D}$ - $\alpha$-tocopherol was started in groups $\mathrm{D}+\mathrm{T}$ and $\mathrm{C}+$ $\mathrm{T}$ (40 mg/kg every other day, ip, up to 30 days of diabetes). All animals were maintained in individual cages with free access of water and food. Thirty days after diabetes induction, or an equivalent period to group $\mathrm{C}$ and $\mathrm{C}+\mathrm{T}$, the renal function studies or microperfusion in vivo measurements were carried out. 


\section{Renal function studies}

The animals were anesthetized with sodium thiopental $(50 \mathrm{mg} / \mathrm{kg})$ and placed on a warmed table to maintain body temperature at $37^{\circ} \mathrm{C}$. A tracheotomy was performed, followed by insertion of polyethylene catheters into the jugular vein for infusion, and into the carotid artery for blood sampling. Urine was collected from a catheter inserted into the bladder. After the surgical procedure, a 1-h stabilization period was allowed to elapse before the beginning of three collection periods. The animals were primed with $1 \mathrm{ml}$ saline containing inulin $(300 \mathrm{mg} / \mathrm{kg})$ and sodium para-aminohippurate (PAH, $2 \mathrm{mg}$ per rat) and then submitted to continuous infusion with saline containing inulin $(15 \mathrm{mg} /$ $\mathrm{ml})$ and PAH ( $4 \mathrm{mg} / \mathrm{l})$ at $0.08 \mathrm{ml} / \mathrm{min}$. Plasma and urine inulin and PAH concentrations were measured by colorimetry for estimation of glomerular filtration rate (GFR) and renal plasma flow (RPF), respectively (16, 17). Filtration fraction ( $\mathrm{FF} \%$ ) was calculated by the formula: GFR/RPF x 100 .

Blood and urine $\mathrm{Na}^{+}$was measured with an ion selective electrode (Ciba-Corning 614 $\mathrm{Na} / \mathrm{K}$ analyzer, Medfield, MA, USA). Fractional $\mathrm{Na}^{+}$excretion $\left(\mathrm{F} \% \mathrm{Na}^{+}\right)$was calculated using the formula: $\left(\mathrm{V} \times\left[\mathrm{Na}^{+}\right] \mathrm{u} /\left[\mathrm{Na}^{+}\right] \mathrm{p}\right.$ $\mathrm{x}$ GFR) x 100; where $\mathrm{V}$ is urinary flow, $\left[\mathrm{Na}^{+}\right] \mathrm{u}$ is sodium urinary concentration, and $\left[\mathrm{Na}^{+}\right] \mathrm{p}$ is plasma sodium concentration.

Net acid excretion was calculated by the formula: $\mathrm{NA}=\mathrm{AT}+\mathrm{NH}_{4}^{+}-\mathrm{C}_{\mathrm{HCO}_{3}}$, where AT is the titratable acidity measured by microtitration, $\mathrm{NH}_{4}{ }^{+}$is ammonium excretion in urine measured by colorimetry, and $\mathrm{C}_{\mathrm{HCO}_{3}}{ }^{-}$ is the amount of bicarbonate excreted in urine (11).

Urinary osmolarity and protein excretion in 24-h urine samples were determined using metabolic cages. Protein concentration was measured by precipitation with $3 \%$ sulfosalicylic acid and osmolarity was measured with an osmometer (Advanced Instruments 3W2, Needham Ham, MA, USA).

\section{In vivo microperfusion measurements}

Proximal acidification was determined on the basis of the half-time of reabsorption of tubular perfused bicarbonate, as previous described (11). Briefly, the kinetics of $\mathrm{HCO}_{3}{ }^{-}$ reabsorption was determined by injecting a droplet of the perfusion solution, $\mathrm{pH} 8.2$, into the proximal convoluted tubules between oil columns and monitoring the intratubular $\mathrm{pH}$ changes toward the steady-state level with a double-barreled microelectrode (18). The perfused segments corresponded to the middle third of the proximal tubule (S2 segment).

Intratubular $\mathrm{pH}$ was measured as the voltage difference between the two barrels of a microelectrode constructed with Hilgenberg (Malsfeld, Germany) double-barreled asymmetric glass capillaries. The larger barrel contained an $\mathrm{H}^{+}$-sensitive ion exchange resin (Fluka, Buchs, Switzerland) and the smaller one contained $1 \mathrm{M} \mathrm{KCl}$ colored with FD \& C green (reference barrel). The transepithelial electrical potential difference was the difference between the reference barrel and the ground. Voltages were read with a WPI (New Haven, CT, USA) model FD223 differential electrometer, the output of which was digitized at 0.5 -s intervals by means of an AD conversion board (Data Translation model DT 2801, Marlborough, MS, USA) mounted on a Dell 333 D microcomputer.

Intratubular concentrations of $\mathrm{HCO}_{3}{ }^{-}$ were calculated from intratubular $\mathrm{pH}$ values and from the systemic partial carbon dioxide pressure $\left(\mathrm{pCO}_{2}\right)$ using the Henderson-Hasselbalch equation at 0.5 -s intervals, since it has been previously demonstrated that renal cortical $\mathrm{pCO}_{2}$ is similar to that of arterial blood (19). The velocity of tubular acidification was determined based on the half-time $(\mathrm{t} / 2)$ of reabsorption of the injected $\mathrm{HCO}_{3}{ }^{-}$. Net $\mathrm{HCO}_{3}{ }^{-}$reabsorption $\left(\mathrm{JHCO}_{3}{ }^{-}\right)$was calculated from the equation: $\mathrm{JHCO}_{3}{ }^{-}=\mathrm{k}$ $\left(\left(\mathrm{HCO}_{3}{ }^{-}\right) \mathrm{i}-\left(\mathrm{HCO}_{3}^{-}\right) \mathrm{s}\right) \mathrm{r} / 2$, where $\mathrm{k}$ is the rate constant of the reduction of luminal bicar- 
bonate $(\mathrm{k}=\ln 2 /(\mathrm{t} / 2)), \mathrm{r}$ is the tubule radius, and $\left(\mathrm{HCO}_{3}^{-}\right) \mathrm{i}$ and $\left(\mathrm{HCO}_{3}{ }^{-}\right) \mathrm{s}$ are the concentrations of the injected $\mathrm{HCO}_{3}{ }^{-}$and $\mathrm{HCO}_{3}{ }^{-}$at the stationary level, respectively.

The microelectrodes were calibrated before and after every impalement on the kidney's surface by superfusion with $20 \mathrm{mM}$ phosphate Ringer buffer solutions containing $130 \mathrm{mM} \mathrm{NaCl}$ at $37^{\circ} \mathrm{C}$, with $\mathrm{pH}$ adjusted to $6.5,7.0$, and 7.5 with $0.1 \mathrm{~N} \mathrm{NaOH}$ or $\mathrm{HCl}$. Under our experimental conditions, the mean slope of 35 microelectrodes was $58.9+2.61$

Table 1. Body weight, kidney weight and relative kidney weight in the animal groups studied.

\begin{tabular}{lcccc}
\hline & \multicolumn{5}{c}{ Group } \\
\cline { 2 - 5 } & $\mathrm{C}$ & $\mathrm{C}+\mathrm{T}$ & $\mathrm{D}$ & $\mathrm{D}+\mathrm{T}$ \\
\hline Body weight $(\mathrm{g})$ & $344.80 \pm 5.64(5)$ & $349.33 \pm 2.67^{\star *}(9)$ & $259.00 \pm 9.31^{*}(10)$ & $301.80 \pm 6.35^{*+}(10)$ \\
Kidney weight $(\mathrm{g})$ & $1.334 \pm 0.033(10)$ & $1.363 \pm 0.048^{* *}(17)$ & $1.638 \pm 0.048^{*}(20)$ & $1.503 \pm 0.039(20)$ \\
Relative kidney weight (\% body weight) & $0.39 \pm 0.01(10)$ & $0.39 \pm 0.01^{* *}(17)$ & $0.64 \pm 0.03^{*}(20)$ & $0.50 \pm 0.01^{*+}(20)$
\end{tabular}

Data are reported as means \pm SEM. The number of measurements is given in parentheses. $C=$ control, $C+T=$ control plus $D$ - $\alpha$-tocopherol, $\mathrm{D}=$ diabetic, $\mathrm{D}+\mathrm{T}=$ diabetic plus $\mathrm{D}$ - $\alpha$-tocopherol.

${ }^{*} \mathrm{P}<0.05$ vs group $\mathrm{C} ;{ }^{+} \mathrm{P}<0.05$ vs group $\mathrm{D} ;{ }^{*} \mathrm{P}<0.05$ vs group $\mathrm{D}+\mathrm{T}$ (ANOVA followed by the Bonferroni test).

Table 2. Glomerular filtration rate (GFR), renal plasma flow (RPF), filtration fraction\% (FF\%), proteinuria, and urine osmolarity (Uosm) in the animal groups studied.

\begin{tabular}{|c|c|c|c|c|}
\hline & \multicolumn{4}{|c|}{ Group } \\
\hline & C & $C+T$ & D & $D+T$ \\
\hline GFR (ml min-1 $\left.\mathrm{kg}^{-1}\right)$ & $6.43 \pm 0.21(25 / 7)$ & $3.74 \pm 0.29^{\star}(35 / 9)$ & $7.74 \pm 0.45^{*}(25 / 7)$ & $3.86 \pm 0.18^{*+}(44 / 12)$ \\
\hline $\operatorname{RPF}\left(\mathrm{ml} \mathrm{min}-1 \mathrm{~kg}^{-1}\right)$ & $17.98 \pm 0.47(25 / 7)$ & $12.84 \pm 0.80 *(35 / 9)$ & $16.53 \pm 1.59(25 / 7)$ & $11.62 \pm 0.68^{*+}(44 / 12)$ \\
\hline $\mathrm{FF} \%$ & $35.86 \pm 0.89(25 / 7)$ & $30.18 \pm 1.98(35 / 9)$ & $51.11 \pm 2.64^{*}(25 / 7)$ & $35.18 \pm 1.33^{+}(44 / 12)$ \\
\hline Proteinuria $(\mathrm{mg} / 24 \mathrm{~h})$ & $12.28 \pm 1.54(11 / 11)$ & $13.24 \pm 2.30(12 / 12)$ & $28.67 \pm 7.27^{*}(11 / 11)$ & $17.23 \pm 2.36(16 / 16)$ \\
\hline Uosm (mosm $/ \mathrm{kg} \mathrm{H} \mathrm{H}_{2} \mathrm{O}$ ) & $2042.64 \pm 139.14(11 / 11)$ & $2253.08 \pm 126.71(12 / 12)$ & $1402.64 \pm 179.73^{*}(11 / 11)$ & $1480.00 \pm 129.13^{*}(16 / 16)$ \\
\hline
\end{tabular}

Data are reported as means \pm SEM. The number of measurements/number of animals is given in parentheses. $\mathrm{C}=\mathrm{control}, \mathrm{C}+\mathrm{T}=\mathrm{control}$ plus $D$ - $\alpha$-tocopherol, $D=$ diabetic, and $D+T=$ diabetic plus $D$ - $\alpha$-tocopherol.

${ }^{*} \mathrm{P}<0.05$ vs group $\mathrm{C} ;{ }^{+} \mathrm{P}<0.05$ vs group $\mathrm{D}$ (ANOVA followed by the Bonferroni test).

Table 3. Acidification half-time (t/2), bicarbonate absorption flux $\left(\mathrm{JHCO}_{3}{ }^{-}\right)$in proximal tubules, net acid excretion (NA), and fractional sodium excretion $\left(\mathrm{F} \% \mathrm{Na}^{+}\right)$in the animal groups studied.

\begin{tabular}{lcccc}
\hline & \multicolumn{4}{c}{ Group } \\
\cline { 2 - 5 } & \multicolumn{1}{c}{$\mathrm{C}$} & $\mathrm{C}+\mathrm{T}$ & $\mathrm{D}$ & $\mathrm{D}+\mathrm{T}$ \\
\hline $\mathrm{t} / 2(\mathrm{~s})$ & $4.75 \pm 0.20(86 / 22)$ & $4.33 \pm 0.17(60 / 18)$ & $3.52 \pm 0.15^{*}(70 / 13)$ & $5.92 \pm 0.19^{+}(105 / 16)$ \\
$\mathrm{JHCO} 3^{-}\left(\mathrm{nmol} \mathrm{cm}^{-2} \mathrm{~s}^{-1}\right)$ & $2.30 \pm 0.10(86 / 22)$ & $2.91 \pm 0.13(60 / 18)$ & $3.28 \pm 0.22^{*}(70 / 13)$ & $1.87 \pm 0.08^{+}(105 / 16)$ \\
$\mathrm{NA}\left(\mu \mathrm{Eq} \mathrm{min}^{-1} \mathrm{~kg}^{-1}\right)$ & $4.52 \pm 0.20(25 / 7)$ & $3.94 \pm 0.28(13 / 4)$ & $6.79 \pm 0.63^{*}(25 / 7)$ & $4.03 \pm 0.24^{+}(18 / 5)$ \\
$\mathrm{F} \% \mathrm{Na}^{+}$ & $0.46 \pm 0.07(25 / 7)$ & $0.59 \pm 0.09(22 / 6)$ & $0.38 \pm 0.07(25 / 7)$ & $0.68 \pm 0.05^{+}(44 / 12)$ \\
\hline
\end{tabular}

Values are reported as means \pm SEM. The number of measurements/number of animals is given in parentheses for $\mathrm{NA}$ and $\mathrm{F} \% \mathrm{Na}^{+}$. The number of measurements/number of proximal tubules studied is given in parentheses for $\mathrm{t} / 2$ and $\mathrm{JHCO}_{3}-\mathrm{C}=\mathrm{control}, \mathrm{C}+\mathrm{T}=\mathrm{control}$ plus $\mathrm{D}$ $\alpha$-tocopherol, $D=$ diabetic, and $D+T=$ diabetic plus $D$ - $\alpha$-tocopherol.

${ }^{*} \mathrm{P}<0.05$ vs group $\mathrm{C} ;{ }^{+} \mathrm{P}<0.05$ vs group $\mathrm{D}$ (ANOVA followed by the Bonferroni test). 
$\mathrm{mV}$ per $\mathrm{pH}$ unit in the 6.5-7.0 range, and 55.4 $+2.38 \mathrm{mV}$ in the 7.0-7.5 range. No significant interference of the presence of cations or anions has been observed (18). The luminal perfusion solution contained $100 \mathrm{mM}$

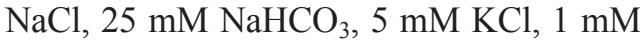
$\mathrm{CaCl}_{2}, 1.2 \mathrm{mM} \mathrm{MgSO}_{4}$, and raffinose to adjust osmolality to 300 mosmol.

\section{Morphological analysis}

The kidneys were dissected, cleaned of connective tissue, weighed, and fixed in Metacarn solution. For morphometric analysis the paraffin-embedded kidney was cut into 5- $\mu \mathrm{m}$ sections and stained with hematoxylin and eosin. Glomerular area and diameters were measured using the Image-ProPlus software.

\section{Statistical analysis}

Data are reported as means \pm SEM. For multiple comparisons, results were analyzed by ANOVA, followed by the Bonferroni test when appropriate. Values that were not normally distributed were analyzed by the Kruskal-Wallis test, followed by Dunn's posttest. The level of significance was set at 0.05 for all analyses.

\section{Results}

Thirty days after the induction of diabetes, blood glucose levels of diabetic rats (D: $408.6 \pm 11.3 \mathrm{mg} / \mathrm{dl})$, and diabetic rats treated with $\mathrm{D}$ - $\alpha$-tocopherol $(\mathrm{D}+\mathrm{T}$ : $352.3 \pm 18.6$ $\mathrm{mg} / \mathrm{dl}$ ) were significantly higher than control $(\mathrm{C}: 85.36 \pm 1.40 \mathrm{mg} / \mathrm{dl})$ and than control treated with $\mathrm{D}-\alpha$-tocopherol $(\mathrm{C}+\mathrm{T}: 89.0 \pm$ $5.2 \mathrm{mg} / \mathrm{dl}$ ). Blood pressure determined in awake animals was similar and within the normal range in all groups studied (C: 119.00 $\pm 1.42 ; \mathrm{C}+\mathrm{T}: 114.32 \pm 1.62 ; \mathrm{D}: 118.44 \pm$ 2.26; D + T: $116.81 \pm 2.24 \mathrm{mmHg}$ ).

Diabetic rats and diabetic rats treated with $\mathrm{D}$ - $\alpha$-tocopherol gained less weight than control and control treated with D- $\alpha$-tocopherol (Table 1). Kidney weight normalized by $100 \mathrm{~g}$ body weight was significantly increased in $\mathrm{D}$ and in $\mathrm{D}+\mathrm{T}$ compared to $\mathrm{C}$ and $\mathrm{C}+\mathrm{T}$. In $\mathrm{D}+\mathrm{T}$ rats, kidney weight was smaller than in $\mathrm{D}$. These parameters are shown in Table 1.

GFR and $\mathrm{FF} \%$ were increased in $\mathrm{D}$ compared to $\mathrm{C}$ (Table 2). In $\mathrm{D}+\mathrm{T}$ and $\mathrm{C}+\mathrm{T}$, GFR was decreased when compared to the groups without $\mathrm{D}$ - $\alpha$-tocopherol treatment. However, FF\% was similar to control values in both $\mathrm{C}+\mathrm{T}$ and $\mathrm{D}+\mathrm{T}$. Twenty-four-hour protein excretion and urinary osmolarity are also shown in Table 2. Diabetic rats presented increased protein excretion compared to controls and decreased urinary osmolarity, probably due to the osmotic effect of glucose in urine. The treatment of diabetic rats with $\mathrm{D}$ - $\alpha$-tocopherol resulted in a slight reduction of protein excretion but had no effect on urinary osmolarity.

Fractional sodium excretion and the kinetic parameters of $\mathrm{HCO}_{3}{ }^{-}$absorption are shown in Table 3. Diabetic rats presented a shorter acidification half-time than controls, with a consequent increase in the rate of bicarbonate absorption, $\mathrm{JHCO}_{3}{ }^{-}$, in the proximal tubules. In $\mathrm{D}+\mathrm{T}$, these alterations were reversed.

The results of morphometric analysis are illustrated in Figure 1. We observed that the glomerular area was increased in diabetic rats when compared to controls. The treatment of diabetic rats with $\mathrm{D}-\alpha$-tocopherol abolished this effect since the glomerular area of this group $(D+T)$ was similar to control.

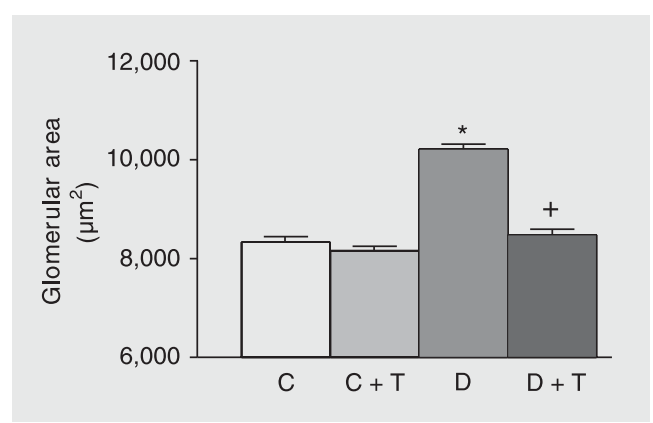

Figure 1. Glomerular area $\left(\mu \mathrm{m}^{2}\right)$ for control (C), control plus D- $\alpha$ tocopherol $(C+T)$, diabetic $(D)$, and diabetic plus $\mathrm{D}$ - $\alpha$-tocopherol $(D+T)$ groups. Glomerulus number/number of histological fields for each group: C, 373/ 44; C + T, 616/70; D, 729/80; D $+T, 505 / 50 .{ }^{*} P<0.05$ vs control; $+\mathrm{P}<0.05$ vs diabetic animals (ANOVA followed by the Bonferroni test). 


\section{Discussion}

Clinical and epidemiological studies have clearly established that hyperglycemia is the major cause of the pathological changes that occur in diabetes $(6,20)$. The mechanisms responsible for the adverse effect of hyperglycemia are probably multiple (6). One of these mechanisms involves the increases in DAG content resulting in the activation of the PKC system. The ability of hyperglycemia to increase DAG content has been reported for glomeruli of diabetic animals $(21,22)$, renal mesangial cells (23), and vascular tissue $(15,24)$.

Treatment with D- $\alpha$-tocopherol has been suggested to be a possible way to prevent some adverse effects of hyperglycemia, probably by its effect on the cellular content of DAG and PKC (25). Kunisaki et al. (26) studied the effect of D- $\alpha$-tocopherol on the glucose-induced increase in PKC activity in cultured smooth muscle cells and in the in vivo aorta of diabetic rats and noticed that $\mathrm{D}$ $\alpha$-tocopherol prevented the activation of the PKC system. Keegan et al. (27) also studied the effect of D- $\alpha$-tocopherol on the aorta of diabetic rats and observed that $\mathrm{D}-\alpha$-tocopherol prevented the defective endotheliumdependent relaxation in these animals. Rosen et al. (28), using the isolated perfused heart of diabetic rats, noted that in these animals the endothelial relaxation in response to 5hydroxytryptamine was impaired and the pretreatment of diabetic rats with tocopherol prevented this alteration.

In the present investigation, we studied the effect of $\mathrm{D}$ - $\alpha$-tocopherol on both glomerular and tubular function. GFR and FF\% were increased in diabetic rats compared to controls, whereas in $\mathrm{D}+\mathrm{T}$ rats this effect was reversed. These results agree with data reported by Koya et al. (22), which showed that hemodynamic abnormalities in diabetic rats were normalized by treatment with $D-\alpha-$ tocopherol. In diabetics rats, hyperfiltration can be caused by a decreased arteriolar resistance, more marked in the preglomerular than in the postglomerular end, increasing the transcapillary hydraulic pressure difference $(\Delta \mathrm{P})$ and also the $\operatorname{GFR}(29,30)$.

Renal afferent and efferent arterioles play an important role in controlling the glomerular hemodynamics. These two microvessels respond differently to a variety of vasoactive substances, including atrial natriuretic peptide and endothelin (31). The constrictor effect of angiotensin, for example, is more pronounced in efferent than in afferent arterioles. This effect has been attributed to PKC activation since staurosporin inhibits this effect (32).

The rats treated with $\mathrm{D}$ - $\alpha$-tocopherol showed a lower GFR than groups C or D. If $D$ - $\alpha$-tocopherol inhibits the activation of PKC, as suggested by several investigators (22,25-28), it could also inhibit the constrictor effect of angiotensin II causing a decrease in $\triangle \mathrm{P}$ and reducing GFR. However, additional studies are necessary to confirm this hypothesis.

Diabetic rats showed increased urinary protein excretion compared to controls. The treatment of diabetic rats with D- $\alpha$-tocopherol caused a small decrease in protein excretion, an effect that may be secondary to the decrease in GFR caused by D- $\alpha$-tocopherol treatment. Koya et al. (22) reported that albuminuria was prevented by treatment with $\mathrm{D}$ - $\alpha$-tocopherol in 10-week diabetic rats; however, Craven et al. (33) did not observe this effect. In the study by Craven et al. (33), DL- $\alpha$-tocopherol acetate was added to the diet, while in the study by Koya et al. (22) the animals received D- $\alpha$-tocopherol $i p$. The use of different forms of vitamin $\mathrm{E}$ and different routes of administration may contribute to the conflicting results reported in the literature.

The osmolarity of 24-h urine was decreased in diabetic rats probably due to the osmotic effect of glucose in urine, which is directly related to glycemia status. Since in D $+\mathrm{T}$ both glycemia and urine osmolarity were 
unchanged when compared to D, we may infer that $\mathrm{D}$ - $\alpha$-tocopherol did not prevent diabetic alterations concerning this aspect of renal function.

The proximal tubule is the nephron segment where about $65 \%$ of the filtered load of $\mathrm{Na}^{+}$is absorbed, and the most important transporter that contributes to $\mathrm{Na}^{+}$absorption is the $\mathrm{Na}^{+} / \mathrm{H}^{+}$exchanger. This transporter exports $\mathrm{H}^{+}$which is buffered by the filtered $\mathrm{HCO}_{3}{ }^{-}$, forming carbonic acid and decreasing luminal $\mathrm{HCO}_{3}{ }^{-}$concentration. Due to the action of carbonic anhydrase, carbonic acid is dehydrated to $\mathrm{CO}_{2}$ that can cross the luminal membrane. Within the cell, $\mathrm{CO}_{2}$ is rehydrated, forming carbonic acid that dissociates to $\mathrm{H}^{+}$and $\mathrm{HCO}_{3}^{-}$, with the latter leaving the cell by an $\mathrm{Na}^{+}$-coupled cotransport (34).

The rate of tubular proximal acidification evaluated by acidification $t / 2$ was faster in diabetic rats than in control animals. This effect resulted in an increased bicarbonate absorption $\left(\mathrm{JHCO}_{3}{ }^{-}\right)$in diabetic rats. These data are compatible with our previous study (11), which showed an increase in $\mathrm{JHCO}_{3}{ }^{-}$in diabetic rats, possibly effected by a higher density of $\mathrm{Na}^{+} / \mathrm{H}^{+}$exchanger in the luminal membrane of proximal tubules. Accordingly, net acid excretion was also increased in the diabetic group, confirming an increased acid secretion in this group. The present results also indicate that $\mathrm{D}$ - $\alpha$-tocopherol alone had no effect on $\mathrm{JHCO}_{3}{ }^{-}$or on net acid excretion, but abolished the stimulatory effect of diabetes on these parameters, probably preventing PKC activation $(22,25-28)$, which has been shown to regulate $\mathrm{Na}^{+} / \mathrm{H}^{+}$exchanger activity (35).

Regarding fractional sodium excretion, we observed that $\mathrm{D}$ - $\alpha$-tocopherol did not affect this parameter in control rats but increased it in $\mathrm{D}+\mathrm{T}$. Considering that $\mathrm{Na}^{+} /$ $\mathrm{H}^{+}$exchanger activity should be increased in diabetic rats ( $\mathrm{t} / 2$ is faster in this group), we may infer that $\mathrm{D}-\alpha$-tocopherol could reduce the activation of PKC and therefore decrease $\mathrm{Na}^{+} / \mathrm{H}^{+}$exchanger activity, leading to increased sodium excretion.

Diabetic rats presented an increased glomerular area, as shown in Figure 1. This change occurred besides the increase of renal mass expressed by absolute or relative kidney weight (per $100 \mathrm{~g}$ body weight; Table 1). Seyer-Hansen (36) showed that kidney weight had already significantly increased after four days of diabetes. The author also suggested that renal hypertrophy was related to the severity of diabetes and that kidney growth rate was associated linearly with blood glucose (37). Increased levels of DAG and PKC can also contribute to this effect (38). In addition, transforming growth factor- $\beta$ (TGF- $\beta$ ) seems important in renal cell hypertrophy and extracellular matrix accumulation in cell culture, as long as the use of anti-TGF- $\beta$-antibodies prevents the hypertrophic and matrix-stimulatory effects of high glucose (39). The morphological parameters (glomerular area and relative kidney weight) of diabetic rats treated with $D-\alpha-$ tocopherol were similar to control, indicating that, probably by its effect on DAG/PKC levels or on TGF- $\beta$ activation, D- $\alpha$-tocopherol could prevent the hypertrophic response to hyperglycemia.

The results reported here suggest that D$\alpha$-tocopherol is able to protect, at least in part, against the harmful effects of diabetes on renal function. In fact, the hypertrophic response usually found in diabetes was prevented by $\mathrm{D}$ - $\alpha$-tocopherol administration; tubular acidification, which was significantly changed by diabetes, also showed values similar to those observed in controls. These results indicate that $\mathrm{D}$ - $\alpha$-tocopherol may be useful against the progression of renal injury usually seen in the chronic diabetic state. 


\section{References}

1. Jacobs C \& Selwood NH (1995). Renal replacement therapy for end-stage renal failure in France: Current status and evolutive trends over the last decade. American Journal of Kidney Diseases, 25: 188-195.

2. National Institute of Diabetes and Digestive and Kidney Diseases (NIDDK) (2004). Kidney and urologic diseases statistics for the United States: Statistics - Kidney problems - End-stage renal disease (ESRD). Available at: http://kidney.niddk.nih.gov. Accessed: February 18, 2004

3. Koya D \& King GL (1998). Protein kinase C activation and the development of diabetic complications. Diabetes, 47: 859-866.

4. Lee AY, Chung SK \& Chung SS (1995). Demonstration that polyol accumulation is responsible for diabetic cataract by the use of transgenic mice expressing the aldose reductase gene in the lens. Proceedings of the National Academy of Sciences, USA, 92: 27802784.

5. Brownlee M (1995). Advanced protein glycosylation in diabetes and aging. Annual Review of Medicine, 46: 223-234.

6. Brownlee M (2001). Biochemistry and molecular cell biology of diabetic complications. Nature, 414: 813-820.

7. Salahudeen AK, Kanji V, Reckelhoff JF \& Schmidt AM (1997). Pathogenesis of diabetic nephropathy: a radical approach. Nephrology, Dialysis, Transplantation, 12: 664-668.

8. Whiteside Cl \& Dlugosz JÁ (2002). Mesangial cell protein kinase C isozyme activation in the diabetic milieu. American Journal of Physiology, 282: F975-F980.

9. Alpern RJ (1990). Cell mechanisms of renal acidification. Physiological Reviews, 70: 79-114

10. Amemiya $M$, Loffing J, Lötscher $M$, Kaissling $B$, Alpern RJ \& Moe OW (1995). Expression of NHE3 in the apical membrane of rat renal proximal tubule and thick ascending limb. Kidney International, 48: 1206-1215

11. Nascimento-Gomes G, Gil FZ \& Mello-Aires M (1997). Alterations of the renal handling of $\mathrm{H}+$ in diabetic rats. Kidney and Blood Pressure Research, 20: 251-257.

12. Mangili R, Bending JJ, Scott G, Li LK, Gupta A \& Viberti GC (1988). Increased sodium-lithium counter-transport activity in red cells of patients with insulin dependent diabetes and nephropathy. New England Journal of Medicine, 318: 146-150.

13. Ng LL, Simmons D, Frighi V, Garrido MC, Bomford J \& Hockaday TDR (1990). Leucocyte $\mathrm{Na}^{+} / \mathrm{H}^{+}$antiport activity in type 1 (insulin dependent) diabetic patients with nephropathy. Diabetologia, 33: 371-377.

14. Trevisan R, Li LK, Messent J, Tariq T, Earle K, Walker JD \& Viberti G (1992). $\mathrm{Na}^{+} / \mathrm{H}^{+}$antiport activity and cell growth in cultured skin fibroblasts of IDDM patients with nephropathy. Diabetes, 41: 12391246.

15. Kunisaki M, Bursell SE, Umeda F, Nawata H \& King GL (1994). Normalization of diacylglycerol-protein kinase $\mathrm{C}$ activation by vitamin $\mathrm{E}$ in aorta of diabetic rats and cultured rat smooth muscle cells exposed to elevated glucose levels. Diabetes, 43: 1372-1377.

16. Fuehr J, Kaczmarczyk J \& Hruttgen CD (1955). Eine einfache colorimetrische Methode zur Inulin Bestimmung für Nieren-Clearance Untersuchungen bei Stoffwechselgesunden und Diabetikern. Klinische Wochenschrift, 33: 729-730.

17. Smith HW, Finkelstein N, Aliminosa L, Crawford B \& Graber M (1945). The renal clearances of substituted hippuric acid derivatives and other aromatic acids in dogs and man. Journal of Clinical
Investigation, 24: 388-404

18. Zaladek-Gil F, Costa-Silva VL \& Malnic G (1995). Effect of luminal calcium on proximal tubule bicarbonate reabsorption in the rat. Renal Physiology and Biochemistry, 18: 271-277.

19. Mello-Aires M, Lopes MJ \& Malnic G (1990). $\mathrm{PCO}_{2}$ in renal cortex. American Journal of Physiology, 259: F357-F365.

20. The Diabetes Control and Complications Trial Research Group (1993). The effect of intensive treatment of diabetes on the development and progression of long-term complications in insulin-dependent diabetes mellitus. New England Journal of Medicine, 329: 977-986

21. Derubertis FR \& Craven PA (1994). Activation of protein kinase $C$ in glomerular cells in diabetes. Mechanisms and potential links to the pathogenesis of diabetic glomerulopathy. Diabetes, 43: 1-8.

22. Koya D, Lee IK, Ishii H, Kanoh H \& King GL (1997). Prevention of glomerular dysfunction in diabetic rats by treatment with d-alphatocopherol. Journal of the American Society of Nephrology, 8: 426435.

23. Kreisberg JI \& Ayo SH (1993). The glomerular mesangium in diabetes mellitus. Kidney International, 43: 109-113.

24. Xia $P$, Inoguchi $T$, Kern TS, Engerman RL, Oates PJ \& King GL (1994). Characterization of the mechanism for the chronic activation of diacylglycerol-protein kinase $\mathrm{C}$ pathway in diabetes and hypergalactosemia. Diabetes, 43: 1122-1129.

25. Venugopal SK, Devaraj S, Yang T \& Jialal I (2002). $\alpha$-Tocopherol decreases superoxide anion release in human monocytes under hyperglycemic conditions via inhibition of protein kinase C- $\alpha$. Diabetes, 51: 3049-3054

26. Kunisaki M, Fumio U, Nawata H \& King L (1996). Vitamin E normalizes diacylglycerol-protein kinase $\mathrm{C}$ activation induced by hyperglycemia in rat vascular tissues. Diabetes, 45: S117-S119.

27. Keegan A, Walbank H, Cotter MA \& Cameron NE (1995). Chronic vitamin $\mathrm{E}$ treatment prevents defective endothelium dependent relaxation in diabetic aorta. Diabetologia, 38: 1475-1478.

28. Rosen P, Ballhausen T, Bloch W \& Addicks K (1995). Endothelial relaxation is disturbed by oxidative stress in diabetic rat heart: influence of tocopherol as antioxidant. Diabetologia, 38: 11571168.

29. Zats R, Meyer TW, Rennke EHG \& Brenner BM (1985). Predominance of haemodynamic rather than metabolic factors in the pathogenesis of diabetic glomerulopathy. Proceedings of the National Academy of Sciences, USA, 82: 5963-5967.

30. Hostetter TH, Troy JL \& Brenner BM (1981). Glomerular hemodynamics in experimental diabetes. Kidney International, 19: 410415.

31. Nagahama T, Hayashi K, Ozawa Y, Takenaka T \& Saruta T (2000). Role of protein kinase $\mathrm{C}$ in angiotensin Il-induced constriction of renal microvessels. Kidney International, 57: 215-223.

32. Takenaka T, Suzuki H, Fujiwara K, Kanno Y, Ohno Y, Hayashi K, Nagahama $T$ \& Saruta $T$ (1997). Cellular mechanisms mediating rat renal microvascular constriction by angiotensin II. Journal of Clinical Investigation, 100: 2107-2114.

33. Craven PA, Derubertis FR, Kagan VE, Melhem M \& Studer RK (1997). Effects of supplementation with vitamin C or E on albuminuria, glomerular TGF- $\beta$, and glomerular size in diabetes. Journal of the American Society of Nephrology, 8: 1405-1414.

34. Greger R (2000). Physiology of renal sodium transport. American Journal of the Medical Sciences, 319: 51-62. 
35. Wiederkehr MR, Zhao H \& Moe OW (1999). Acute regulation of $\mathrm{Na} / \mathrm{H}$ exchanger NHE3 activity by protein kinase $\mathrm{C}$ : role of $\mathrm{NHE3}$ phosphorylation. American Journal of Physiology, 276: C1205C1217.

36. Seyer-Hansen K (1997). Renal hypertrophy in experimental diabetes: some functional aspects. Journal of Diabetic Complications, 1: 7-10.

37. Seyer-Hansen K (1983). Renal hypertrophy in experimental diabe- tes mellitus. Kidney International, 23: 643-646.

38. Ayo SH, Radnik R, Garoni JA, Troyer DA \& Kreisberg JI (1991). High glucose increases diacylglycerol mass and activates protein kinase $\mathrm{C}$ in mesangial cell cultures. American Journal of Physiology, 261 (Part 2): F571-F577.

39. Bollineli JS \& Reddi AS (1993). Transforming growth factor-beta 1 enhances glomerular collagen synthesis in diabetic rats. Diabetes, 42: 1673-1677. 